\title{
PENERAPAN METODE COST AND BENEFIT ANALYSIS DALAM PENGUKURAN INVESTASI TEKNOLOGI INFORMASI (STUDY KASUS : CV LAUT SELATAN JAYA)
}

\author{
The Application of Cost and Benefit Analysis Methods in Measuring \\ Information Technology Investment \\ (Case Study : CV Laut Selatan Jaya) \\ Miswanto $^{1}$, Heni Sulistiani' ${ }^{2}$, Damayanti ${ }^{3)}$ \\ ${ }^{1,3)}$ Sistem Informasi, Universitas Teknokrat Indonesia \\ ${ }^{2)}$ Sistem Informasi Akuntansi, Universitas Teknokrat Indonesia \\ Jl. ZA. Pagaralam No. 9-11, Labuhan Ratu, Bandar Lampung \\ email: miswanto095@gmail.com, henisulistiani@teknokrat.ac.i.d, damayanti@teknokrat.ac.id
}

\begin{abstract}
ABSTRAK
Seiring dengan perkembangan teknologi saat ini, kebutuhan teknologi dalam dunia bisnis menjadi sangat penting dalam menentukan kemajuan suatu perusahaan. Besarnya nilai nominal investasi teknologi informasi (TI) khususnya untuk sistem informasi (SI) pada perusahaan, membuat banyak pihak mulai bertanya-tanya bagaimana cara memperkirakan seberapa besar investasi tersebut memberikan manfaat bagi perusahaan. Agar nilai investasi terhadap teknologi dapat diukur, maka diperlukan suatu strategi yang dapat mengukur besarnya biaya dan nilai manfaat dari investasi TI tersebut. Dengan adanya pengukuran investasi TI diharapkan bahwa investasi yang akan dilakukan sesuai dengan kebutuhan organisasi serta sejalan dengan visi dan misi instansi terkait.

Pengembangan sistem menggunakan metode Extreme Programming, dan perancangan sistem menggunakan UML. Agar penelitian ini tidak bersifat subjektif maka penulis juga menggunakan metode penelitian berupa pengamatan, tinjauan pustaka, dokumentasi. Hasil pengujian sistem menggunakan ISO 9126 dengan karakteristik functionality $87.43 \%$ dan usability $85.00 \%$ yang telah dilakukan dengan melibatkan 5 Responden sehingga memiliki persentase hasil dengan total rata-rata 86.89\%. Nilai persentase yang diperoleh menunjukkan kualitas perangkat lunak keseluruhan mempunyai skala "Baik" dan dinilai layak untuk diterapkan pada CV Laut Selatan Jaya.
\end{abstract}

Kata Kunci : Cost Benefit Analysis, Extreme Programming, Investasi Teknologi Informasi.

\section{Pendahuluan}

Seiring dengan perkembangan teknologi saat ini, kebutuhan teknologi dalam dunia bisnis menjadi sangat penting dalam menentukan kemajuan suatu perusahaan. Banyak perusahaan yang kini menyadari bahwa salah satu kunci untuk meraih sukses dalam kompetisi dunia bisnis sangat bergantung pada kemampuan dalam memperoleh informasi yang berguna secara cepat dan tepat salah satunya pada nominal investasi. Untuk mengantisipasi timbulnya permasalahan yang berkaitan dengan pengelolaan data akuntansi di masa yang akan datang dan untuk saat ini, diperlukan sebuag sistem yang dapat meniminalisir kendala yang terjadi (Sulistiani, dkk 2018).

Besarnya nilai nominal investasi teknologi informasi (TI) khususnya untuk sistem informasi (SI) pada perusahaan, membuat banyak pihak mulai bertanya-tanya bagaimana cara memperkirakan seberapa besar investasi tersebut memberikan manfaat bagi perusahaan. Fakta menyatakan bahwa manfaat investasi SI dapat berupa yang terhitung (tangible) maupun yang tidak terhitung (intangible). Manfaat ini juga ada yang dapat dirasakan secara langsung dan ada juga yang hanya dapat dirasakan setelah jangka waktu tertentu. Hal ini menyebabkan banyak perusahaan mengalami kesulitan bagaimana menghitung nilai investasi SI dikaitkan dengan manfaat yang dihasilkan (Rusmi, 2010). Sistem informasi pengukuran investasi ini dapat diterapkan pada CV Laut Selatan Jaya.

CV Laut Selatan Jaya merupakan anak perusahaan dari PT Mandom Indonesia Tbk, yang berlokasi di Jl. Laks. Malahayati No. 58, Pesawahan, Teluk Betung Selatan, Kota Bandar Lampung, Lampung. CV Laut Selatan Jaya merupakan perusahaan yang bergerak dalam bidang distribusi penjualan kosmetik di Bandar Lampung. Dalam proses penjualan pada CV Laut Selatan Jaya telah menggunakan software aplikasi Azetechsoft Internet untuk mengelola transaksi penjualan. Aplikasi Azetechsoft Internet merupakan aplikasi akuntansi yang berguna untuk memudahkan aktivitas pencatatan penjualaan, persediaan, dan 
pembelian. Perusahaan mengeluarkan biaya yang tidak sedikit untuk membangun aplikasi tersebut. Nilai nominal yang dikeluarkan perusahaan termasuk dalam investasi teknologi. Agar nilai investasi terhadap teknologi dapat diukur, maka diperlukan suatu strategi yang dapat mengukur besarnya biaya dan nilai manfaat dari investasi TI tersebut. Dengan adanya pengukuran investasi TI diharapkan bahwa investasi yang akan dilakukan sesuai dengan kebutuhan organisasi serta sejalan dengan visi dan misi instansi terkait (Widjanadi, 2012).

Dalam pengukuran investasi TI harus menggunakan strategi yang tepat. Beberapa metode yang dapat digunakan untuk pengukuran investasi adalah Cost Benefit Analysis (CBA), Information Economics (IE), Value Analysis, IT Valuation Matrix (Hendarti, 2012). Salah satu metode yang akan digunakan untuk mengukur investasi TI pada sistem penjualan di CV Laut Selatan Jaya yaitu Cost Benefit Analysis (CBA). Metode tersebut digunakan untuk menentukan atau menghitung nilai dari setiap elemen teknologi informasi yang memiliki kontribusi terhadap biaya yang dikeluarkan dan manfaat yang diperoleh (Sulistiani \& Dellia, 2016) . Analisis kelayakan ekonomis dilakukan dengan memanfaatkan alat analisis finansial yang ada, seperti Net Present Value (NPV) (Istiarni, 2014). Dari hasil analisis tersebut, dapat memberikan pertimbangan atas manfaat yang dihasilkan dari investasi penggunaan aplikasi penjualan pada CV Laut Selatan Jaya. Untuk itu dalam usulan penelitian ini akan membahas dan menerapkan metode Cost Benefit Analysis (CBA) untuk pengukuran investasi IT pada CV Laut Selatan jaya.

\section{Landasan Teori}

\subsection{Metode Pengembangan Sistem}

Extreme Programming (XP) adalah metodologi pengembangan perangkat lunak yang ditujukan untuk meningkatkan kualitas perangkat lunak dan tanggap terhadap perubahan kebutuhan pelanggan. Jenis pengembangan perangkat lunak semacam ini dimaksudkan untuk meningkatkan produktivitas dan memperkenalkan pos pemeriksaan di mana persyaratan pelanggan baru dapat diadopsi (Pressman, 2012). Pendekatan yang digunakan dalam Extreme Programming adalah object-oriented sebagai paradigma pengembangan dan mencakup seperangkat aturan.

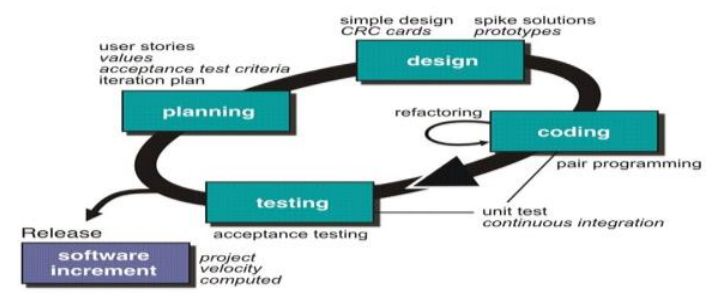

Gambar .1 Extreme Programming

\subsection{Perancangan Sistem UML (Unified Modeling} Language)

Menurut Rosa A.S dan M. Shalahuddin (2011:133). "UML (Unified Modeling Language) adalah salah satu standar bahasa yang banyak digunakan di dunia industri untuk mendefinisikan requirement, membuat analisis \& desain, serta menggambarkan arsitektur dalam pemrograman berorientasi objek".

\section{Hasil Pembahasan}

Hasil pembahasan ini menggunakan metode pengumpulan data yaitu pengamatan, wawancara, tinjauan pustaka, dan dokumentasi.

\subsection{Desain Sistem}

Desain sistem merupakan tahap yang menentukan proses dan data yang diperlukan oleh sistem baru. Desain sistem ini merupakan gambaran secara menyeluruh mengenai urutan pengolahan data dari persiapan desain sistem sampai menghasilkan laporan yang dibutuhkan.

\subsubsection{Usecase Diagram}

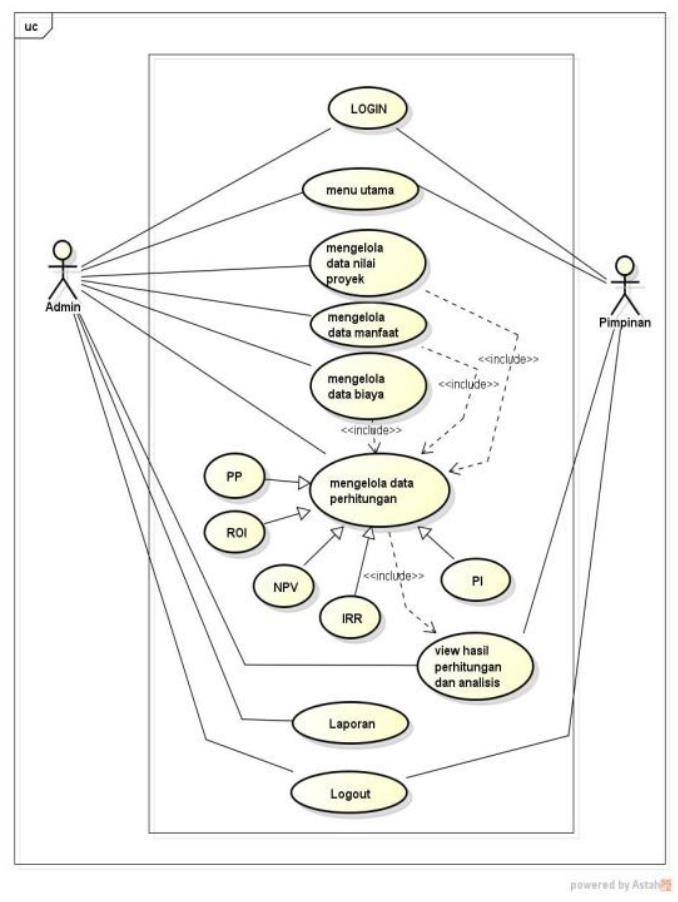

Gambar 2 Usecase Diagram 


\subsubsection{Class Diagram}

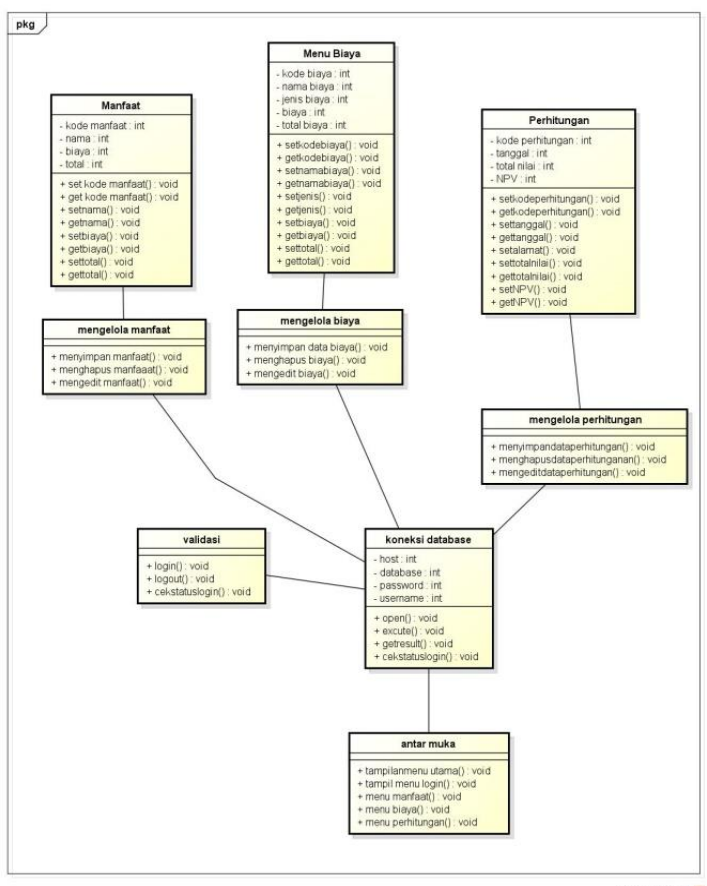

Gambar 3 Class Diagram

\subsection{Tampilan Program}

\subsubsection{Implementasi Menu Login}

Menu login adalah tampilan untuk masuk kedalam sistem disini admin dapat memasukkan username dan password yang sudah tedaftar, serta terdapat tombol login yang digunakan untuk masuk kedalam sistem. Adapun tampilannya sebagai berikut:

\section{Administrator}

Login

\begin{tabular}{|c|c|}
\hline admin & $\Omega$ \\
\hline$\bullet \bullet \bullet \bullet \bullet$ & 0 \\
\hline
\end{tabular}

\section{Sign In}

Gambar 4 Implementasi Menu Login

\subsubsection{Tampilan yang Diakses Admin}

\subsubsection{Implementasi Menu Utama Admin}

Menu utama adalah tampilan awal program admin. Pada menu utama, admin dapat memasukkan nilai proyek, biaya, nilai manfaat, dan perhitungan NPV, IRR, ROI, PP dan PI serta cetak. Adapun tampilannya sebagai berikut:

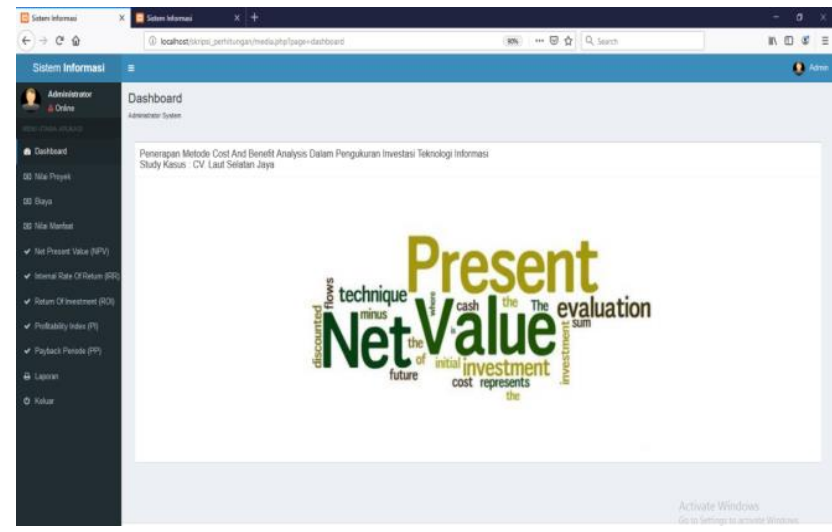

\section{Gambar 5 Implementasi Menu Utama}

\subsubsection{Implementasi Menu Nilai Proyek}

Menu proyek adalah tampilan untuk memasukkan data nilai proyek. Pada menu nilai proyek, admin dapat memasukkan nama biaya dan biaya, dan terdapat tombol simpan untuk menyimpan dan tombol batal untuk membatalkan. Adapun tampilannya sebagai berikut:

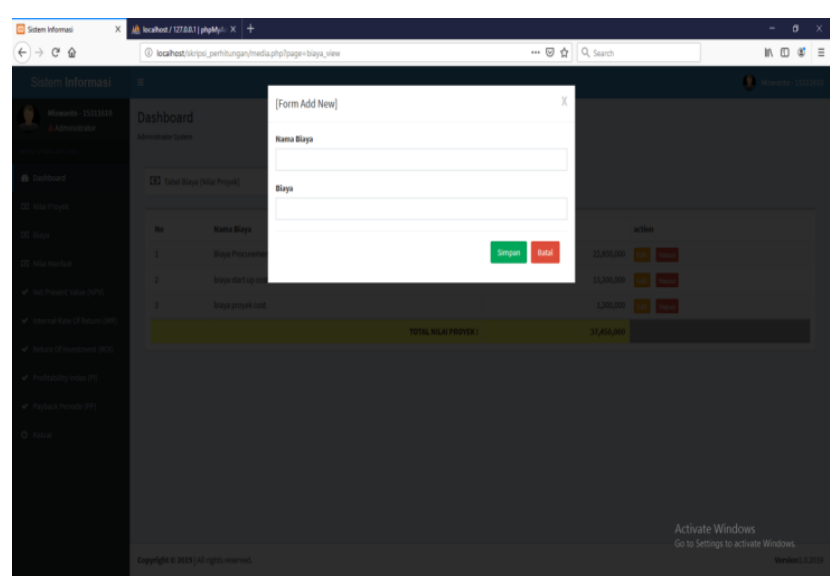

Gambar 6 Implementasi Menu Nilai Proyek

Setelah admin memasukkan data nilai proyek, terdapat tombol edit untuk melakukan pengeditan dan tombol hapus untuk menghapus data yang sudah dimasukkan. Adapun tampilannya sebagai berikut: 


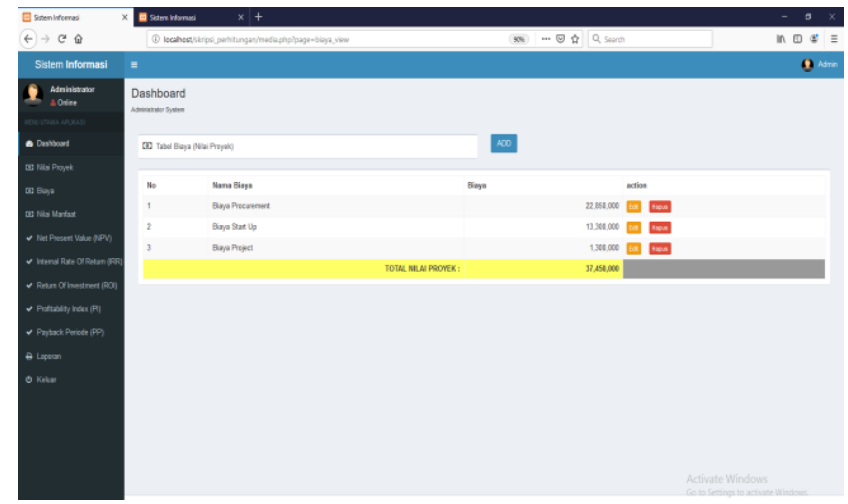

Gambar 7 Implementasi Menu Tabel Nilai Proyek

\subsubsection{Implementasi Menu Biaya}

Menu biaya adalah tampilan untuk memasukkan data biaya. Pada menu biaya, admin dapat memasukkan nama biaya dan biaya, dan terdapat tombol simpan untuk menyimpan dan tombol batal untuk membatalkan. Adapun tampilannya sebagai berikut:

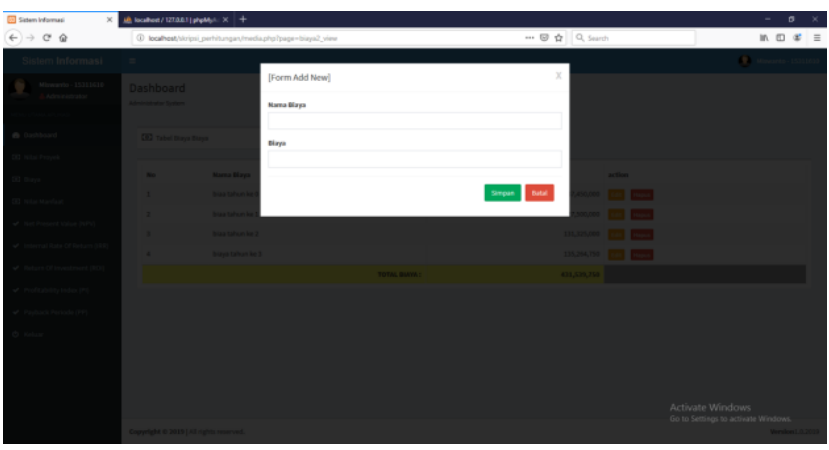

Gambar 8 Implementasi Menu Biaya

Setelah admin memasukkan data biaya, terdapat tombol edit untuk melakukan pengeditan dan tombol hapus untuk menghapus data yang sudah dimasukkan. Adapun tampilannya sebagai berikut:

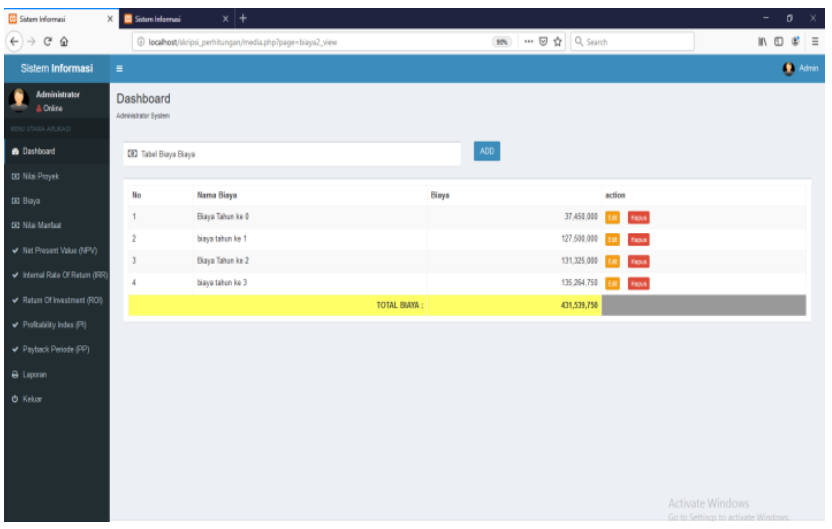

Gambar 9 Implementasi Menu Tabel Biaya

\subsubsection{Implementasi Menu Nilai Manfaat}

Menu nilai manfaat adalah tampilan untuk memasukkan data nilai manfaat. Pada menu nilai manfaat, admin dapat memasukkan nama nilai manfaat, nilai manfaat, nilai biaya dan nama cash flow, dan terdapat tombol simpan untuk menyimpan dan tombol batal untuk membatalkan. Adapun tampilannya sebagai berikut:

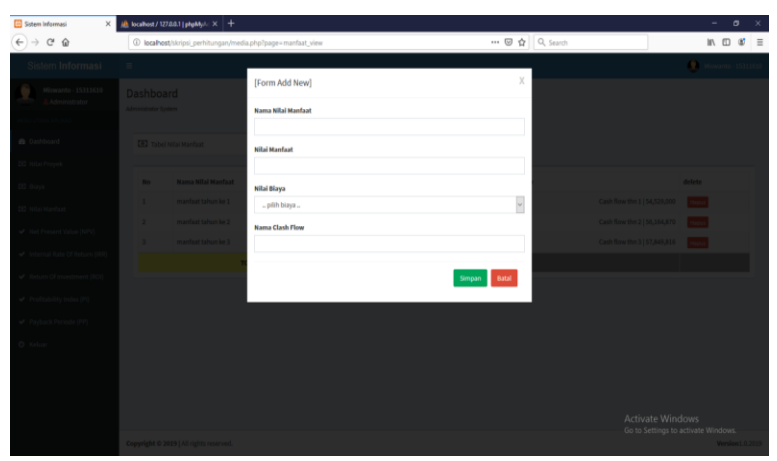

Gambar 9 Implementasi Menu Nilai Manfaat

Setelah admin memasukkan data nilai manfaat, terdapat tombol hapus untuk menghapus data yang sudah dimasukkan. Adapun tampilannya sebagai berikut:

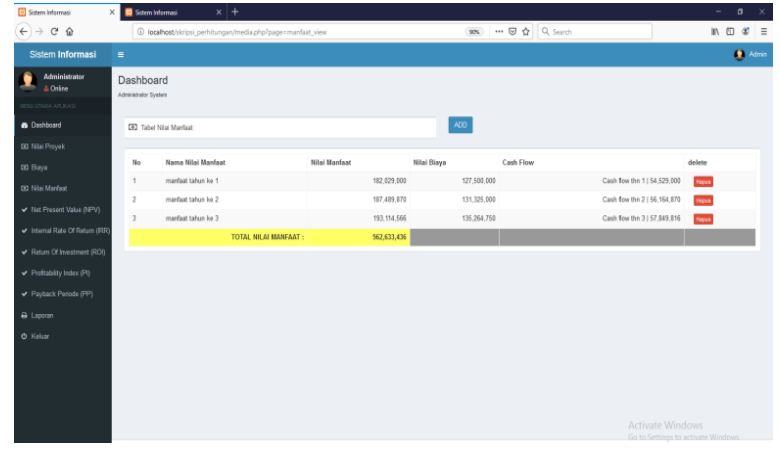

\section{Gambar 10 Implementasi Menu Tabel Nilai Manfaat}

\subsubsection{Implementasi Menu NPV}

Menu NPV adalah tampilan untuk melakukan perhitungan NPV. Pada menu NPV admin dapat memasukkan data total nilai proyek dan cash flow, serta terdapat tombol hitung untuk melakukan perhitungan. Adapun tampilannya sebagai berikut:

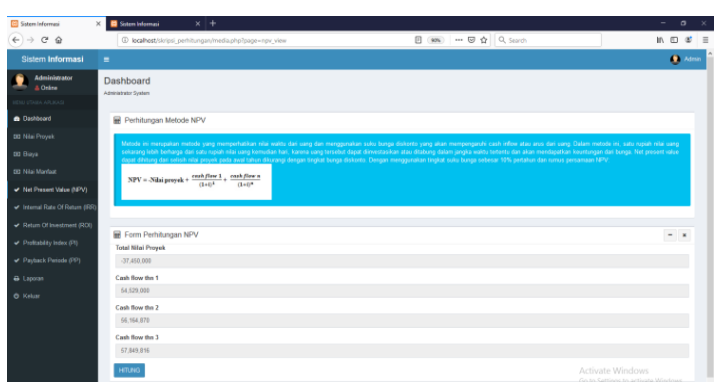

Gambar 11 Implementasi Menu NPV 
Setelah admin memasukkan data NVP dan dihitung, maka akan muncul hasil perhitungan dan analisis, serta terdapat tombol kembali untuk kembali ke menu perhitungan dan tombol simpan untuk menyimpan. Adapun tampilannya sebagai berikut:

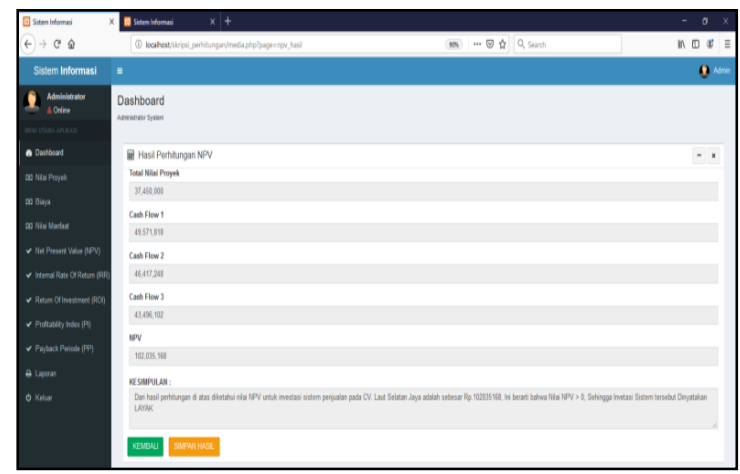

Gambar 12 Implementasi Menu Hasil NPV

\subsubsection{Implementasi Menu IRR}

Menu IRR adalah tampilan untuk melakukan perhitungan IRR. Pada menu IRR admin dapat memasukkan data total investasi awal, cash flow dan IRR disyaratkan, serta terdapat tombol hitung untuk melakukan perhitungan. Adapun tampilannya sebagai berikut:

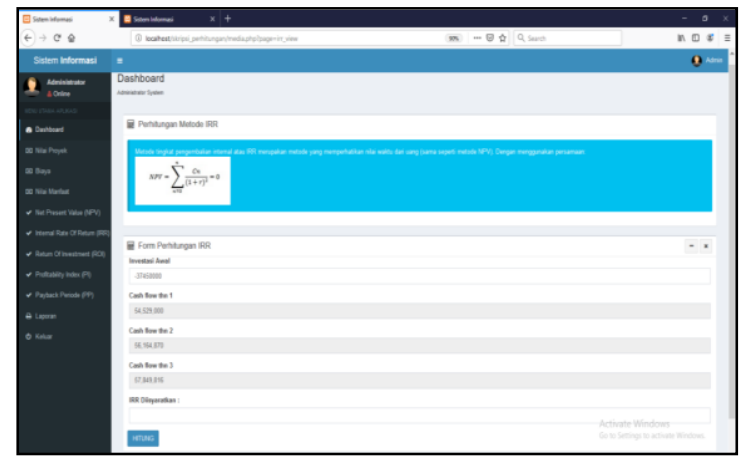

Gambar 13 Implementasi Menu IRR

Setelah admin memasukkan data IRR dan dihitung, maka akan muncul hasil perhitungan dan analisis, serta terdapat tombol kembali untuk kembali ke menu perhitungan dan tombol simpan untuk menyimpan. Adapun tampilannya sebagai berikut:

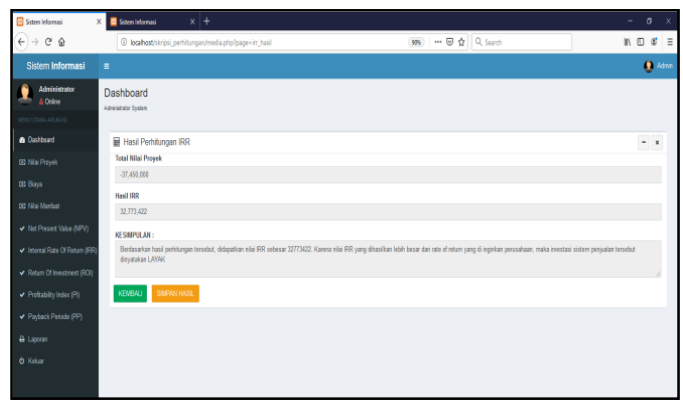

Gambar 14 Implementasi Menu Hasil IRR

\subsubsection{Implementasi Menu ROI}

Menu ROI adalah tampilan untuk melakukan perhitungan ROI. Pada menu ROI admin dapat memasukkan total manfaat dan total biaya, serta terdapat tombol hitung untuk melakukan perhitungan. Adapun tampilannya sebagai berikut:

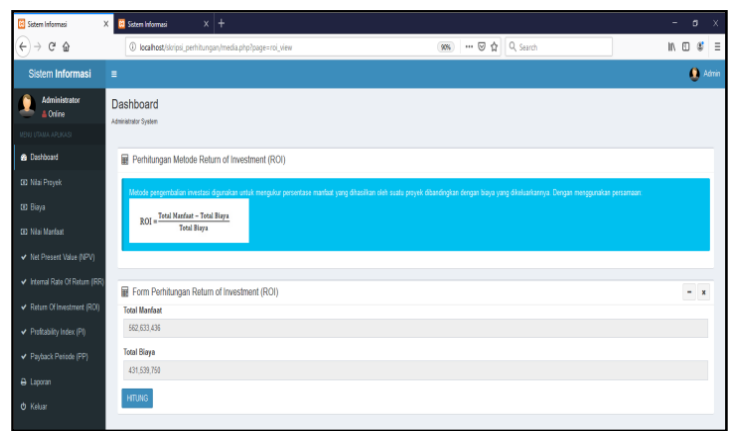

Gambar 15 Implementasi Menu ROI

Setelah admin memasukkan data ROI dan dihitung, maka akan muncul hasil perhitungan dan analisis, serta terdapat tombol kembali untuk kembali ke menu perhitungan dan tombol simpan untuk menyimpan. Adapun tampilannya sebagai berikut:

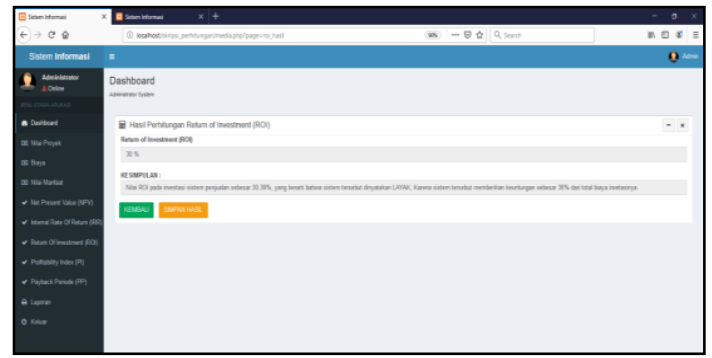

Gambar 16 Implementasi Menu Hasil ROI

\subsubsection{Implementasi Menu PI}

Menu PI adalah tampilan untuk melakukan perhitungan PI. Pada menu PI admin dapat memasukkan nilai investasi awal dan nilai hasil dari NPV, serta terdapat tombol hitung untuk melakukan perhitungan. Adapun tampilannya sebagai berikut:

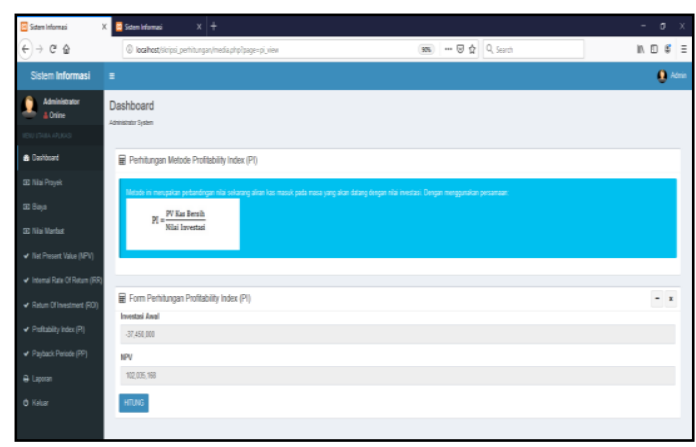

Gambar 17 Implementasi Menu PI 
Setelah admin memasukkan data PI dan dihitung, maka akan muncul hasil perhitungan dan analisis, serta terdapat tombol kembali untuk kembali ke menu perhitungan dan tombol simpan untuk menyimpan.

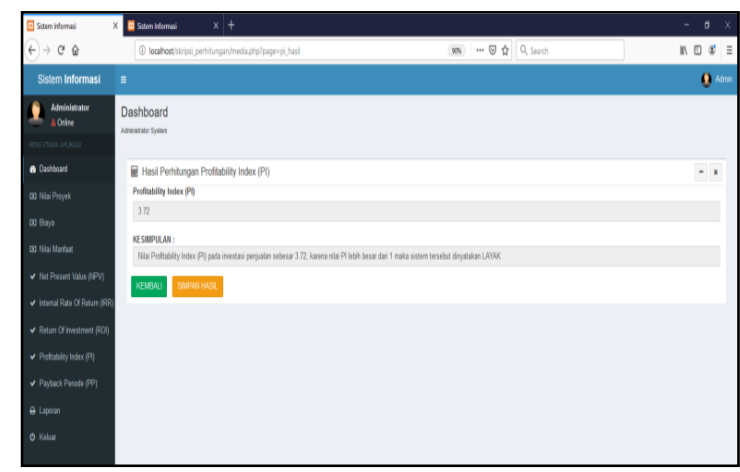

Gambar 18 Implementasi Menu Hasil PI

\subsubsection{Implementasi Menu PP}

Menu PP adalah tampilan untuk melakukan perhitungan PP. Pada menu PP admin dapat memasukkan nilai manfaat dan aliran kas, serta terdapat tombol hitung untuk melakukan perhitungan.

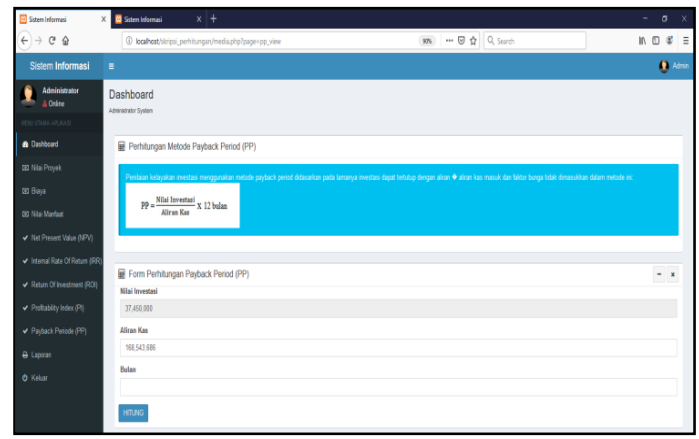

Gambar 19 Implementasi Menu PP

Setelah admin memasukkan data PP dan dihitung, maka akan muncul hasil perhitungan dan analisis, serta terdapat tombol kembali untuk kembali ke menu perhitungan dan tombol simpan untuk menyimpan.

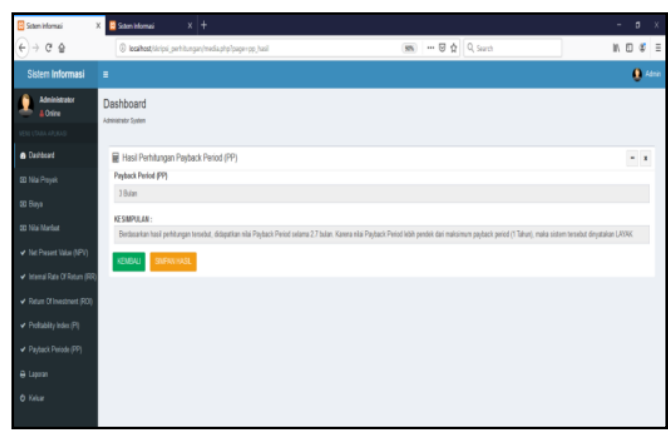

Gambar 20 Implementasi Menu Hasil PP

\subsubsection{Implementasi Menu Cetak laporan}

Menu cetak laporan adalah tampilan untuk melakukan cetak. Pada menu cetak admin dapat melakukan cetak hasil perhitungan. Adapun tampilannya sebagai berikut:

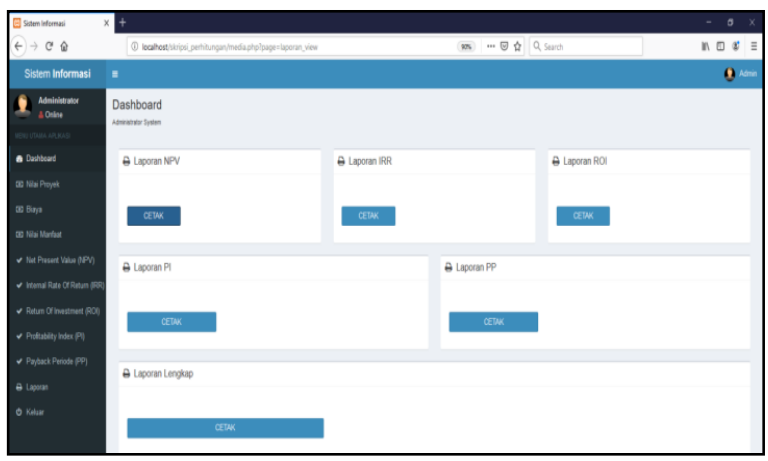

Gambar 21 Implementasi Menu Cetak Laporan

Setelah admin masuk ke menu laporan maka akan muncul hasil cetak laporan. Adapun tampilannya sebagai berikut:

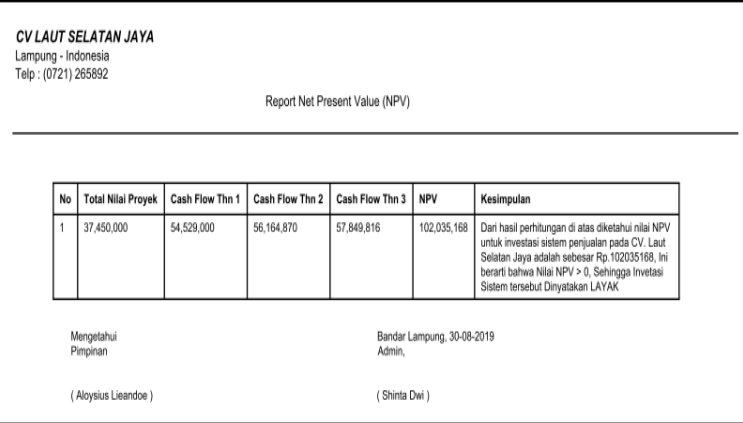

Gambar 22 Implementasi Hasil Cetak Laporan

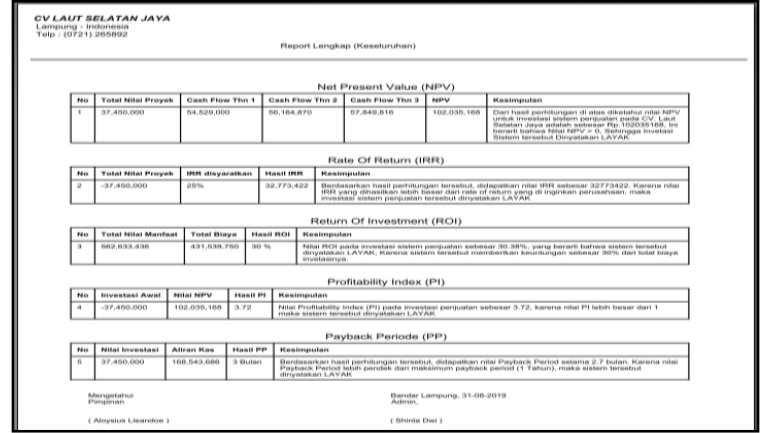

Gambar 23 Implementasi Hasil Cetak Laporan Lengkap

Pada penelitian ini tahap testing dilakukan setelah tahap implementasi sistem dengan menjalankan aplikasi dan melihat apakah ada kesalahan atau tidak, kemudian dilakukan pengujian ISO 9126 yang memiliki enam karakteristik yaitu Functionality, Reliability, Ussability, 
Efficiency, Portability, Maintannability (Sari, 2016). Pada penelitian ini penulis hanya menggunakan dua karakteristik yaitu funcionality dan ussability. Dalam melakukan pengujian ini dilakukan oleh 3 orang karyawan CV Laut Selatan Jaya, dan 2 orang Dosen (1 Dosen SI dan 1 Dosen Akuntansi), berikut adalah hasil perhitungan pengujian dan hasil pengujian dilampirkan :

Tabel 1 Skala Konversi Nilai

\begin{tabular}{|c|c|}
\hline $\begin{array}{c}\text { Persentase } \\
\text { Pencapaian (\%) }\end{array}$ & Interpretasi \\
\hline $84,01-100$ & Sangat Baik \\
\hline $68,01-84$ & Baik \\
\hline $52,01-68$ & Cukup \\
\hline $36,01-52$ & Kurang \\
\hline $20-36$ & Sangat Kurang \\
\hline
\end{tabular}

Sumber: Wicaksono (2016)

Dari pengujian yang diulas pada sub-bab sebelumnya, didapatkan beberapa hasil kuesioner yang dipaparkan pada sub-bab ini. Penulis melakukan survei dengan CV Laut Selatan Jaya. Kuisioner yang dibuat masing-masing pernyataan merepresentasikan dari karakteristik kualitas yang diujikan.

Berdasarkan hasil pengujian kualitas perangkat lunak yang dibangun dalam karakteristik functionality admin pada aplikasi yang dibangun memiliki hasil persentase keberhasilan sebesar $\mathbf{8 8 . 8 6 \%}$. Nilai yang diperoleh tersebut selanjutnya dikonversi berdasarkan skala konversi nilai produk. Dapat disimpulkan bahwa nilai persentase yang diperoleh menunjukkan kualitas perangkat lunak karakteristik functionality mempunyai skala "Baik" sehingga dapat dikatakan bahwa aplikasi yang dibangun sudah memenuhi karakteristik functionality.

Sedangkan hasil pengujian kualitas perangkat lunak yang dibangun dalam karakteristik usability pada aplikasi memiliki hasil persentase keberhasilan sebesar $\mathbf{8 5 . 0 0 \%}$. Nilai yang diperoleh tersebut selanjutnya dikonversi berdasarkan skala konversi nilai produk. Dapat disimpulkan bahwa nilai persentase yang diperoleh menunjukkan kualitas perangkat lunak karakteristik usability mempunyai skala "Baik" sehingga dapat dikatakan bahwa aplikasi yang dibangun sudah memenuhi karakteristik usability.

Berikut hasil pengujian ISO 9126 secara keseluruhan pada aplikasi dapat dilihat pada tabel 2 di bawah ini:

Tabel 2 Hasil Keseluruhan Pengujian ISO 9126

\begin{tabular}{|l|c|c|c|c|}
\hline \multicolumn{1}{|c|}{ Aspek } & Skor Aktual & Skor Ideal & \% Skor Aktual & Kriteria \\
\hline Functionality & 311 & 350 & 88,86 & Baik \\
\hline Usability & 85 & 100 & 85,00 & Baik \\
\hline Total & 396 & 450 & 88 & Baik \\
\hline
\end{tabular}

Berdasarkan hasil pengujian ISO 9126 yang telah dilakukan dengan melibatkan 5 Responden bahwa kesimpulan kualitas kelayakan perangkat lunak yang dihasilkan memiliki persentase keberhasilan dengan total rata-rata $\mathbf{8 8 \%}$. Sehingga dapat disimpulkan bahwa nilai persentase yang diperoleh menunjukkan kualitas perangkat lunak secara keseluruhan mempunyai skala "Baik".

\section{Kesimpulan}

Bedasarkan hasil pembahasan yang telah dilakukan, maka dapat disimpulkan sebagai berikut :

1. Penerapan metode Cost Benefit Analysis (CBA) dalam pengukuran investasi pada CV Laut Selatan Jaya dengan cara melakukan perhitungan NPV, RRI, ROI, PI dan PP akan menampilkan hasil analisis secara cepat dan akurat.

2. Pembangunan sistem informasi pengukuran investasi pada CV Laut Selatan Jaya dimulai dari metode pengumpulan data (wawancara, pengamatan dan dokumentasi) menggunakan metode pengembangan extreme programming sehingga pembuatan rancangan system menggunakan UML yaitu dengan model perancangan Usecase Diagram, Activity Diagram, dan Class Diagram. Dengan menggunakan pengujian ISO 9126 dengan kualitas kelayakan perangkat lunak yang dihasilkan memiliki persentase keberhasilan dengan total rata-rata $\mathbf{8 6 . 8 9 \%}$. Sehingga dapat disimpulkan bahwa nilai persentase yang diperoleh menunjukkan kualitas perangkat lunak secara keseluruhan mempunyai skala "Baik" untuk penjabaran kuisioner terkait pengujian ISO 9126.

\section{Saran}

Berdasarkan simpulan dari hasil penelitian yang telah diuraikan, maka saran yang dapat diberikan untuk pengembangan lebih lanjut yaitu :

1. Operator/user yang menggunakan sistem ini sebaiknya memiliki pengetahuan yang cukup tentang kegunaan/oprasional program agar dalam pelaksanaannya tidak memiliki hambatan. Dapat juga dilakukan sosialisasi terlebih dahulu kepada operator/user.

2. Diharapkan penelitian selanjutnya menambahkan grafik hasil perhitungan

3. Untuk mendukung kelancaran dan kinerja dari sistem informasi ini perlu diadakan pemeliharaan (maintenance) yang baik dan teratur.

\section{REFERENSI}

[1] Hendarti, Henny. 2012. Analisis Investasi Sistem Informasi Dengan Menggunakan Metode Information Economics. Seminar Nasional Aplikasi Teknologi Informasi. 106-111.

[2] Istiarni. 2014. Analisis Pengaruh Perpepsi Manfaat. Andi. Yogyakarta. 
[3] Pressman. 2010. Pendekatan Praktisi Rekayasa. Perangkat Lunak. Edisi 7. Penerbit Andi. Yogyakarta.

[4] Rosa, A.S. dan M. Shalahuddin. 2018. Rekayasa Perangkat Lunak. Modula. Bandung.

[5] Rusmin. 2012. Analisis Investasi Teknologi Informasi di Perguruan Tinggi dengan Metode Cost-Benefit Analysis (CBA). Jurnal IJSN. 39-44.

[6] Sari, Tika Novita. 2016. Analisis Kualitas dan Pengembangan Sistem Informasi Akademik Berbasis Web menggunakan Standard ISO 9126. Jurnal Informatika dan Komputer (JIKO), Vol. 1, No. 1, Februari 2016.

[7] Sulistiani, Heni dan Dellia Prita. 2016. Evaluasi Kelayakan Investasi Teknologi Informasi Menggunakan Metode Cost Benefit Analysis. Jurnal Konferensi Nasional Sistem Informasi. 1-7.
[8] Sulistiani, Heni, Retno Triana \& Neneng Neneng. 2018. Sistem Informasi Akuntansi Pengelolaan Piutang Usaha untuk Menyajikan Pernyataan Piutang (Open Item Statement) Pada PT Chandra Putra Globalindo. Jurnal Tekno Kompak 12 (2), pp. 34-38.

[9] Wicaksono, Harjunadi. 2016. Audit Kualitas Software ERP Axapta menggunakan Standard ISO 9126. Bina Insani ICT Journal, Vol. 3, No. 1, Juni 2016, pp. 107-121.

[10] Widjanadi, Imelia. 2012. Analisa Investasi Sistem Informasi Administrasi Pada Distributor $\mathrm{X}$ dengan Menggunakan Metode Information Economics. Jurnal IT. 1-10. 